\title{
Aplikasi Lampu Penerangan Rumah Tinggal Sederhana (Solar Home System) Berbasis Tenaga Surya Di SMA Pancaran Berkat Jakarta Barat
}

\author{
J. M. Tambunan ${ }^{1}$; Tri Joko P. ${ }^{2}$; M. Bangkit S. ${ }^{3}$; Hastuti Azis ${ }^{4}$; Pawenary ${ }^{5}$; Sri Yayi $^{6}$ \\ 1, 2, 3, 4, 5, ${ }^{6}$ Fakultas Ketenagalistrikan dan Energi Terbarukan, Institut Teknologi PLN \\ ${ }^{1}$ juaramangapult_stmsi@yahoo.com
}

\begin{abstract}
This P2M training activity is an EBT (Renewable Energy) application training activity which is held by IT-PLN lecturers and students in the faculty of Electrical Engineering. This training is held to train students who are in high school on household lighting and remote areas in Indonesia. The training was held at Pancaran Berkat High School, Grogol, West Jakarta. The P2M team gave an explanation of how to plan the design and install solar home panels on the roof of a house or building using poles and explain the functions of the work and its benefits in people's lives. Solar energy is an alternative energy that has great potential in Indonesia. This renewable energy has been developed using the photovoltaic method commonly known as the Photovoltaic Solar Power Plant. Development planning consists of the amount of power needed in daily use, how much current generated by solar cell panels (in Ampere Hour) uses Solar Home System (SHS) for simple house. The results of the presentation of Solar Home System is the students were enthusiastic to hear and get new knowledge about New Renewable Energy, especially solar energy. Besides that, SMA Pancaran Berkat as a partner gets added value in cooperation with universities, in this case IT-PLN.
\end{abstract}

Keywords: Solar cell, solar home system, lighting, SMA Pancaran Berkat

\begin{abstract}
ABSTRAK
Kegiatan pelatihan P2M ini merupakan kegiatan pelatihan aplikasi EBT (Energi Baru Terbarukan) yang dimotori oleh para Dosen dan mahasiswa IT-PLN di bidang Teknik Elektro. Pelatihan ini berguna untuk melatih siswa-siswi yang duduk dibangku sekolah menengah mengenai lampu penerangan rumah tangga serta daerah-daerah terpencil di Indonesia. Pelatihan diadakan di SMA Pancaran Berkat, Jakarta yang berlokasi di Grogol, Jakarta Barat. Tim P2M memberikan paparan tentang bagaimana merencanakan rancang bangun dan memasang solar home panel di atas atap rumah di atas bangunan menggunakan tiang dan menjelaskan fungsi kerja serta manfaatnya didalam kehidupan masyarakat. Energi surya merupakan energi alternatif yang memiliki potensi besar di Indonesia. Energi terbarukan ini telah dikembangkan dengan metode fotovoltaik yang secara umum dikenal sebagai Pembangkit Listrik Tenaga Surya Fotovoltaik. Perencanaan pembangunan terdiri dari jumlah daya yang dibutuhkan dalam pemakaian sehari-hari, berapa besar arus yang dihasilkan solar cell panel (dalam Ampere Hour) menggunakan Solar Home System (SHS) untuk rumah tinggal sederhana. Hasil dari pemaparan Solar Home System para siswa-siswi antusias mendengar dan mendapat pengetahuan baru mengenai Energi Baru Terbarukan khususnya energi surya. Selain itu SMA Pancaran Berkat sebagai mitra mendapat nilai tambah kerja sama dengan perguruan tinggi, dalam hal ini IT-PLN.
\end{abstract}

Kata kunci: Sel surya, solar home system, lampu penerangan, SMA Pancaran Berkat 


\section{PENDAHULUAN}

Dalam menanggapi krisis energi yang terjadi, pemerintah mengupayakan berbagai cara untuk mengembangkan berbagai energi alternatif. Indonesia yang berada pada daerah khatulistiwa dan akan selalu disinari matahari selama 10 - 12 jam dalam sehari. Maka potensi untuk mengembangkan potensi energi surya sangatlah besar. Total intensitas penyinaran rata-rata $5,8 \mathrm{kWh}$ per meter persegi per hari, matahari bersinar berkisar 2.000 jam per tahun, sehingga tergolong kaya sumber energi matahari.

Data Ditjen Listrik dan Pengembangan Energi pada tahun 2002, kapasitas terpasang listrik tenaga surya di Indonesia mencapai 3,56 MW dari potensi yang tersedia 6,8 x $10^{9} \mathrm{MW}$. Dengan potensi yang cukup besar tersebut diharapkan energi surya ini dapat membantu dalam memenuhi kebutuhan energi bangsa ini dan juga mengurangi ketergantungan kita terhadap pemakaian energi fosil.

Potensi energi matahari di Indonesia telah teridentifikasi di beberapa lokasi terutama di wilayah Jawa, Sulawesi Selatan, Nusa Tenggara dan Maluku. Hingga tahun 2025 direncanakan pengembangan potensi PLTS sebesar 2.500 MW. Solusi yang ditawarkan, dalam hal ini adalah siswa-siswi SMA/SMK agar dapat mampu menyerap ilmu yang terkait dengan energi baru dan terbarukan, sehingga mampu menerapkan sistem PLTS sederhana dalam kehidupan sehari-hari. Bagaimana mengetahui potensi energi surya sebagai energi yang terbarukan di Indonesia. Apa sajakah komponen utamanya pada solar home system untuk rumah tinggal sederhana. Bagaimana siswa-siswi dapat mampu membuat perhitungan sederhana di dalam rancang bangun solar home system dengan PLTS tersebut. Bagaimana siswa-siswi dapat melakukan cara pemasangan perangkat solar home system secara tepat dan terarah oleh sinar matahari.

Adapun kegiatan ini merupakan suatu konsep untuk memberikan tanggungjawab yang lebih besar kepada siswa siswi SMA/SMK tentang bagaimana cara menerapkan TET yang bermanfaat dalam kehidupan, dan pekerjaan. Pemberdayaan akan berhasil jika dilakukan oleh pengusaha, pemimpin dan kelompok yang dilakukan secara terstruktur dengan membangun budaya kerja yang baik. Konsep pemberdayaan tersebut terkait dengan pengertian pembangunan yang bertumpu pada masyarakat.

Program-program pemberdayaan sumber daya manusia ini telah dilakukan pemerintah. Seiring dengan tujuan pembangunan Indonesia yaitu membangun manusia Indonesia seutuhnya, maka pembangunan harus menitikberatkan pada perubahan sosial masyarakat yang tidak hanya terjadi baik dalam taraf kehidupan sosial masyarakat yang tinggi begitupun dalam kalangan masyarakat bawah. Pembangunan menempatkan manusia sebagai subyek pembangunan. Pemberdayaan masyarakat dalam mengembangkan masalah energi menjadi komitmen bersama antara pemerintah pusat dengan pemerintah daerah. Namun banyaknya keterbatasan yang dimiliki pemerintah baik pusat maupun daerah mengakibatkan banyak wilayah yang seharusnya menjadi prioritas justru terabaikan. Dari rasa kepedulian itulah kami terpanggil untuk ikut berperan dalam kegiatan Indonesia mengajar, dengan mengikutsertakan mahasiswa, dosen dan masyarakat. Dengan melalui pelatihan TET dengan aplikasi penggunaan Solar Home System (SHS) untuk Lampu Penerangan Rumah Tinggal inilah merupakan salah satu program yang dikembangkan oleh mahasiswa dan dosen IT-PLN, dan pengembangan pelatihan ini secara gratis untuk siswa-siswi SMA/SMK. 


\section{METODE PELAKSANAAN}

Metode pelaksanaan yang digunakan dalam tim P2M di sini adalah berupa Pelatihan Aplikasi Lampu Penerangan Rumah Tinggal Sederhana (Solar Home System) di SMA Pancaran Berkat, Jakarta yang telah dilaksanakan dalam satu sesi, diikuti oleh kurang lebih 50 siswa. Kegiatan ini dilaksanakan dalam jangka waktu kurang lebih 4 (empat) hari kerja. Siswa diberikan materi berupa pengetahuan tentang aplikasi pembangkit listrik tenaga surya (PLTS) dan diberi kebebasan bertanya tentang aplikasi Solar Home System dengan PLTS, sehingga siswa mampu menerapkan sistem PLTS sederhana dalam kehidupan sehari-hari, mengetahui potensi energi matahari, mengetahui komponen perancangan Solar Home System, inverter DC ke AC, Solar Charge Controller serta AKI dan mampu membuat perhitungan sederhana mengenai rancang bangun Solar Home System dengan PLTS.

Adapun prosedur dalam metode pelaksanaan kegiatan P2M yang dilakukan adalah sebagai berikut :

Langkah 1 : Siswa diberikan teori tentang dasar-dasar PLTS

Langkah 2 : Penyajian dan peragaan alat rangkaian dan komponen-komponen PLTS

Langkah 3 : Simulasi aplikasi PLTS untuk lampu penerangan di sekolah dengan menggunakan miniatur papan Solar Home System untuk PLTS yang telah disiapkan.

Langkah 4 : Siswa-siswa diberi kesempatan untuk melakukan simulasi sendiri dengan menggunakan miniatur PLTS yang telah disiapkan.

Langkah 5 : Siswa diberikan tahapan perencanaan, perancangan dan pengoperasian aplikasi PLTS untuk lampu penerangan disekolah.

\section{HASIL DAN PEMBAHASAN}

a. HASIL

Hasil yang dicapai dari kegiatan Program Kemitraan Masyarakat melalui Pelatihan Aplikasi Pembangkit Listrik Tenaga Surya (PLTS) untuk lampu penerangan rumah tinggal sederhana dengan (solar home system) di SMA Kristen Pancaran Berkat di Grogol Jakarta Barat adalah sebagai berikut :

a. Dapat dilihat dari antusiasnya semua peserta yang mengikuti pelatihan tersebut, yaitu pada saat diberi kesempatan berdiskusi tanya jawab oleh tim untuk bertanya maka semua peserta ingin bertanya lebih banyak tentang bagaimana metode dalam perancangan solar cell PLTS untuk rumah tinggal sederhana menggunakan solar home system. Bahkan setelah acara presentasi PKM selesai, masih ada peserta yang hendak bertanya kepada tim PKM. Peserta telah memahami bagaimana manfaat dan keunggulan yang diperoleh melalui energi surya sebagai energi terbarukan di Indonesia yang menjadi faktor pendukung bagi kehidupan masyarakat yang tertinggal.

b. Tim PKM, telah menunjukkan keahliannya dengan mempraktekkan ilmu dan keterampilan yang dimilikinya terkait dalam bidang perencanaan pembangkit listrik tenaga surya (PLTS) untuk skala rumah tinggal sederhana khususnya lampu-lampu penerangan.

Bagi IT PLN, citra IT-PLN menjadi baik dan dikenal di mata masyarakat umum terutama siswa-siswi dan guru SMA Pancaran Berkat dalam meningkatkan kualitas hidup masyarakat sekitarnya, dan lebih mempererat hubungan civitas akademika IT-PLN dengan warga masyarakat terutama siswa-siswi dan guru SMA Pancaran Berkat di wilayah Jakarta Barat.

Hasil PKM setelah pelatihan, siswa-siswi SMA Pancaran Berkat Jakarta Barat dapat dibekali dalam prakteknya dan mampu menyerap ilmu yang terkait dengan energi baru dan terbarukan dengan baik yang dipaparkan oleh tim PKM bisa dilihat dari antusiasnya semua peserta yaitu dalam diskusi tanya jawab maka semua peserta ingin mengetahui lebih luas tentang merancang bangun dan biaya pembuatan PLTS untuk skala rumah tinggal tersebut. Dengan ketersediaan 
informasi tentang komponen-komponen PLTS tersebut, peserta makin mengetahui potensi yang dihasilkan oleh energi surya yang menjadi salah satu sumber energi terbarukan yang murah dan mudah didapat di Indonesia. Disamping bebas dari polusi udara dan bebas dari faktor-faktor keburukan lainnya, terutama bagi lingkungan dan kesehatan masyarakat sekitarnya.

Capaian luaran yang dihasilkan adalah sebagai berikut :

a. Adanya informasi melalui jurnal yang dipublikasikan pada jurnal perguruan tinggi.

b. Peningkatan perkembangan terhadap kemajuan IPTEK di masyarakat terutama siswa-siswi SMA Pancaran Berkat Jakarta, yang diindikasikan dengan antusiasnya peserta dalam diskusi tanya jawab yang diberikan.

Hak kekayaan intelektual berupa modul pelatihan aplikasi pembangkit listrik tenaga surya (PLTS) dengan solar home system (SHS).
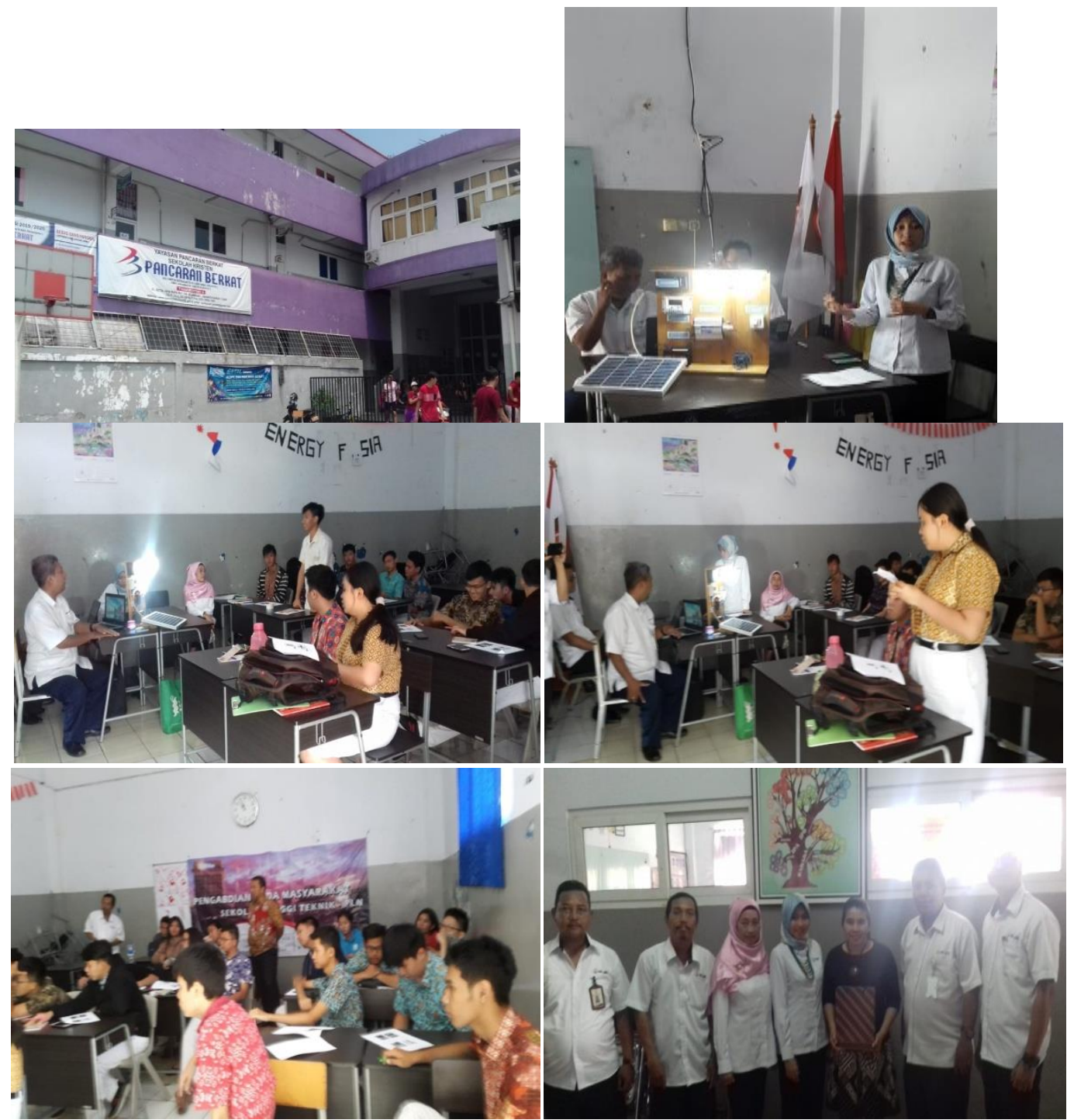


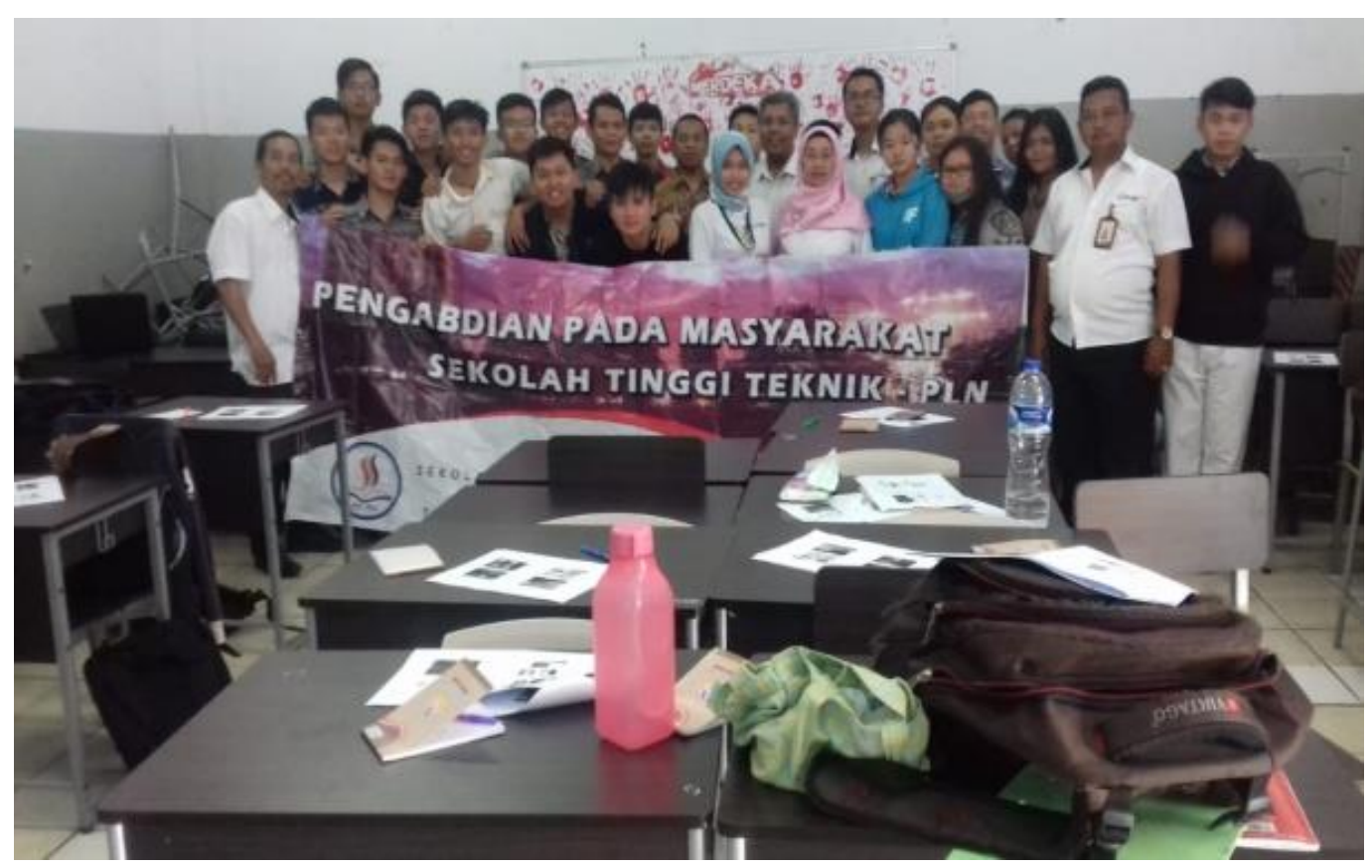

Gambar 1. Foto-Foto Kegiatan P2M

\section{b. PEMBAHASAN}

Pengujian Sel Surya berikut ini adalah data hasil pengujian sel surya, dimana dilakukan di kampus IT-PLN (Area Lab Energi Terbarukan), pada tanggal 26 Nopember 2018. Pengujian dilakukan satu hari dengan mewakili kondisi sinar matahari disiang hari. Pengujian ini bertujuan untuk mengetahui keberfungsian dan unjuk kerjanya. Pengujian ini dilakukan dengan cara memberikan sumber cahaya matahari terhadap area sel surya. Data hasil pengujian adalah sebagai berikut:

- Kondisi solar cell tidak terkena sinar matahari (posisi solar cell terbalik), tegangan terukur adalah $262.3 \mathrm{mV}-\mathbf{2 6 3 . 7} \mathrm{mV}$.

- Kondisi solar cell terkena sinar matahari, didapat data hasil pengukuran selama 10 menit adalah sebagai berikut:

Tabel 1. Hasil Pengujian Sel Surya

\begin{tabular}{|c|c|}
\hline T (Menit) & $\begin{array}{c}\text { TeganganTerukur } \\
(\mathbf{V})\end{array}$ \\
\hline 1 & 17.14 \\
\hline 2 & 17.54 \\
\hline 3 & 17.52 \\
\hline 4 & 17.39 \\
\hline 5 & 17.95 \\
\hline 6 & 18.02 \\
\hline 7 & 17.95 \\
\hline 8 & 17.97 \\
\hline 9 & 17.56 \\
\hline 10 & 17.95 \\
\hline
\end{tabular}


Perubahan posisi atau kemiringan solar cell saat dilakukan pengujian akan berpengaruh terhadap daya serap cahaya. Nilai tegangan akan berubah ketika ada perubahan intensitas cahaya matahari. Dengan demikian, menempatkan area solar cell terkena cahaya atau tidak bertujuan untuk mengetahui solar cell berfungsi atau tidak berfungsi.

Berdasarkan hasil pengujian diatas yang dilakukan per satu menit selama waktu 10 menit, tegangan yang didapat sesuai dengan karakteristik modul photovoltaic (Rated Operating Voltage $=$ $17,10 \mathrm{~V}$ ). Tegangan kerja normal dari tegangan $17.14 \mathrm{~V}$ sampai dengan $17.95 \mathrm{~V}$, maka dapat diketahui fungsi solar cell sudah berfungsi dengan baik dan dapat digunakan untuk mengisi accumulator.

Berikut ini adalah tabel hasil pengujian proses pengisian accumulator menggunakan sumber tegangan dari solar cell. Kondisi tegangan awal pada accumulator sebelum proses charging adalah 7,4 Volt (layak untuk dilakukan charging), bertujuan untuk memenuhi tegangan maksimum accumulator sebesar 12 Volt.

Tabel 2. Proses Pengisian Accumulator menggunakan solar cell

\begin{tabular}{|c|c|c|c|}
\hline T (Menit) & $\begin{array}{c}\text { Tegangan } \\
\text { Terukur }(\mathbf{V})\end{array}$ & T (Menit) & $\begin{array}{c}\text { Tegangan } \\
\text { Terukur }(\mathrm{V})\end{array}$ \\
\hline 1 & 7.44 & 20 & 9.37 \\
\hline 2 & 8.12 & 21 & 9.42 \\
\hline 3 & 8.31 & 22 & 9.45 \\
\hline 4 & 8.12 & 23 & 9.48 \\
\hline 5 & 8.31 & 24 & 9.53 \\
\hline 6 & 8.42 & 25 & 9.57 \\
\hline 7 & 8.51 & 26 & 9.62 \\
\hline 8 & 8.59 & 27 & 9.68 \\
\hline 9 & 8.66 & 28 & 9.74 \\
\hline 10 & 8.70 & 29 & 9.94 \\
\hline 11 & 8.77 & 30 & 10.00 \\
\hline 12 & 8.84 & 31 & 10.08 \\
\hline 13 & 8.89 & 32 & 10.14 \\
\hline 14 & 8.96 & 33 & 10.18 \\
\hline 15 & 9.02 & 34 & 10.22 \\
\hline 16 & 9.08 & 35 & 10.26 \\
\hline 17 & 9.20 & 36 & 10.29 \\
\hline 18 & 9.27 & 37 & 10.34 \\
\hline 19 & 9.33 & 38 & 10.38 \\
\hline T (Menit) & $\begin{array}{c}\text { Teganga } \\
\text { Terukur }(\mathbf{V})\end{array}$ & T (Menit) & $\begin{array}{c}\text { Teganga } \\
\text { Terukur (V) }\end{array}$ \\
\hline 39 & 10.41 & 60 & 11.29 \\
\hline 40 & 10.46 & 61 & 11.34 \\
\hline 41 & 10.49 & 62 & 11.37 \\
\hline 42 & 10.53 & 63 & 11.42 \\
\hline 43 & 10.57 & 64 & 11.46 \\
\hline
\end{tabular}


Terang: Jurnal Pengabdian Pada Masyarakat Menerangi Negeri

e-ISSN: $2655-5948$

Vol. 2, No. 2, Juli 2020

P-ISSN: 2655-5956

DOI: https://doi.org/10.33322/terang.v2i2.409

Hal. $117-125$

\begin{tabular}{|l|l|}
\hline 44 & 10.62 \\
\hline 45 & 10.65 \\
\hline 46 & 10.69 \\
\hline 47 & 10.72 \\
\hline 48 & 10.75 \\
\hline 49 & 10.79 \\
\hline 50 & 10.82 \\
\hline 51 & 10.84 \\
\hline 52 & 10.86 \\
\hline 53 & 10.91 \\
\hline 54 & 10.99 \\
\hline 55 & 11.04 \\
\hline 56 & 11.08 \\
\hline 57 & 11.15 \\
\hline 58 & 11.19 \\
\hline 59 & 11.25 \\
\hline
\end{tabular}

\begin{tabular}{|l|l|}
\hline 65 & 11.48 \\
\hline 66 & 11.53 \\
\hline 67 & 11.55 \\
\hline 68 & 11.57 \\
\hline 69 & 11.58 \\
\hline 70 & 11.59 \\
\hline 71 & 11.63 \\
\hline 72 & 11.66 \\
\hline 73 & 11.69 \\
\hline 74 & 11.75 \\
\hline 75 & 11.79 \\
\hline 76 & 11.85 \\
\hline 77 & 11.89 \\
\hline 78 & 11.94 \\
\hline 79 & 11.97 \\
\hline 80 & 12.01 \\
\hline
\end{tabular}

Keterangan :

$\mathrm{T}$ (Menit) : Lamanya waktu yang dibutuhkan untuk proses charging.

$\mathrm{V}$ (Volt) : Tegangan yang didapat oleh accumulator dari hasil charging sumber tegangan solar cell.

Pengisian ini tergantung kondisi tingkat kecerahan. Jika solar cell mendapatkan sinar matahari pada terik cuaca tinggi, maka tegangan yang didapat akan besar dan cepat diterima. Sebaliknya, jika cuaca mendung atau solar cell kurang mendapatkan sinar matahari, maka tegangan yang didapat selama proses pengisian accumulator akan menurun dan lambat. Hal ini teruji dari hasil pengujian proses pengisian accumulator menggunakan sumber tegangan solar cell.

\section{KESIMPULAN}

Dengan kegiatan Pengabdian Pada Masyarakat yang telah dilaksanakan ini, penulis dapat mengambil kesimpulan bahwa pelaksanaan kegiatan ini memberikan nilai tambah bagi siswa-siswi SMA Pancaran Berkat Jakarta dan sekolah itu sendiri yaitu dapat menjadi nilai tambah bagi pengetahuan tentang teknologi energi surya (matahari) yang dapat digunakan sebagai pembangkit tenaga listrik, siswa-siswi mengetahui potensi energi baru terbarukan (EBT) seperti energi sinar matahari, mengetahui komponen-komponen pembangkit listrik tenaga surya (PLTS). Energi surya merupakan energi alternatif yang memiliki potensi cukup besar di Indonesia. Energi terbarukan ini telah dikembangkan dengan dua metode yaitu energi surya fotovoltaik yang secara umum dikenal sebagai Pembangkit Listrik Tenaga Surya Fotovoltaik (PLTS Fotovoltaik).

Pembangkit listrik tenaga surya ini sangat tergantung kepada sinar matahari, maka perencanaan yang baik sangat diperlukan. Perencanaan terdiri dari Jumlah daya yang dibutuhkan dalam pemakaian sehari-hari (Watt), berapa besar arus yang dihasilkan solar cell panel (dalam Ampere Hour) menggunakan Solar Home System (SHS) untuk rumah tinggal sederhana, dalam hal ini memperhitungkan berapa jumlah panel surya yang harus dipasang dan berapa unit baterai yang diperlukan untuk kapasitas yang diinginkan dan pertimbangan penggunaan tanpa sinar matahari (Ampere Hour). Dan sekolah SMA Pancaran Berkat sebagai mitra mendapat nilai tambah kerja sama dengan perguruan tinggi, dalam hal ini IT PLN. 


\section{SARAN}

Disamping potensi Energi Baru Terbarukan (EBT) dalam hal ini energi surya atap yang besar tersebut terutama energi matahari, maka rencana kedepan dalam melaksanakan kegiatan P2M, tim Pengabdian Pada Masyarakat Teknik Elektro IT-PLN akan terus melanjutkan sosialisasi kepada masyarakat tentang penggunaan teknologi energi matahari, begitu pula energi angin yang dapat menghasilkan listrik baik melalui pelatihan-pelatihan maupun simulasi singkat terutama diperuntukkan pada siswa-siswa SMA maupun SMK sebagai bekal siswa sebelum menyelesaikan studinya, sehingga mereka memiliki gambaran pengetahuan dan wawasan yang luas dalam memantapkan pilihan mereka dalam melanjutkan pendidikan mereka ke jenjang pendidikan yang lebih tinggi.

Dalam kegiatan pelatihan aplikasi pembangkit yang berbasis energi baru terbarukan (EBT) seperti energi matahari ini sangat perlu terus dilakukan terutama kepada masyarakat terlebih khusus kepada generasi muda, dalam hal ini siswa-siswi SMA / SMK yang merupakan ujung tombak generasi penerus bangsa. Energi baru terbarukan sangat melimpah di Indonesia sehingga diharapkan kedepannya para generasi penerus bangsa ini dapat melakukan banyak pengkajian dan penerapan teknologi energi baru dan terbarukan ini.

\section{UCAPAN TERIMA KASIH}

Penulis beserta seluruh tim dosen dan mahasiswa P2M Teknik Elektro IT-PLN juga ingin mengucapkan banyak terima kasih kepada pihak LP3M IT-PLN Jakarta atas dukungannya yang akan memberikan dana P2M dan segala macam arahan dan bantuan yang diberikan kepada tim kami sehingga kami dapat menyelesaikan laporan kegiatan P2M ini dengan baik dan lancar.

Laporan Kegiatan P2M ini disadari masih terdapat banyak kekurangan didalamnya karena itu kami mohon saran dan masukan dari berbagai pihak yang senantiasa kami nantikan sehingga kami bisa memperbaiki pada laporan P2M selanjutnya. Terima kasih. 


\section{DAFTAR PUSTAKA}

[1] Anonim. 2017. National Energy Summit, Integration for Sustainability. Jakarta www.lenterabumi.com/lenteraangin (terakhir diakses tgl 15 Maret 2018

[2] Anonim.2017. Mewujudkan Program Nawacita: "Powering the Archipelago". Kementrian Energi dan Sumber Daya Mineral, Direktorat Jendral Energi Baru Terbarukan dan Konservasi Energi. Jakarta

[3] Muhibbur Rohman, 2012. "Optimalisasi Perancangan Solar Home System Menggunakan Homer". Makalah, Fakultas Teknik Elektro, Universitas Muhammadiyah Surakarta. Solo

[4] Nova Rachmadona, Zurriyati, 2014. "Makalah Konversi Energi". Politeknik Negeri Sriwijaya. Palembang.

[5] Nyoman S. Kumara. 2010. "Pembangkit Listrik Tenaga Surya Skala Rumah Tangga Urban Dan Ketersediaannya Di Indonesia". Jurnal Teknologi Elektro, Vol.9 No.1, Universitas Udayana. Bali. 